\title{
Article \\ Silicon Nanoparticles Improve the Shelf Life and Antioxidant Status of Lilium
}

\author{
Juan Francisco Sánchez-Navarro ${ }^{1}$, Yolanda González-García ${ }^{2}$, Adalberto Benavides-Mendoza ${ }^{3} \mathbb{D}$, \\ América Berenice Morales-Díaz ${ }^{4}$, Susana González-Morales ${ }^{5}{ }^{\circledR}$, Gregorio Cadenas-Pliego ${ }^{6}{ }^{(0)}$, \\ María del Socorro García-Guillermo ${ }^{7}$ and Antonio Juárez-Maldonado ${ }^{2, *(\mathbb{D})}$
}

check for updates

Citation: Sánchez-Navarro, J.F.;

González-García, Y.;

Benavides-Mendoza, A.;

Morales-Díaz, A.B.;

González-Morales, S.;

Cadenas-Pliego, G.; García-Guillermo,

M.d.S.; Juárez-Maldonado, A. Silicon

Nanoparticles Improve the Shelf Life and Antioxidant Status of Lilium.

Plants 2021, 10, 2338. https://

doi.org/10.3390/plants10112338

Academic Editor:

Vasileios Fotopoulos

Received: 18 September 2021

Accepted: 26 October 2021

Published: 29 October 2021

Publisher's Note: MDPI stays neutral with regard to jurisdictional claims in published maps and institutional affiliations.

Copyright: (c) 2021 by the authors. Licensee MDPI, Basel, Switzerland. This article is an open access article distributed under the terms and conditions of the Creative Commons Attribution (CC BY) license (https:/ / creativecommons.org/licenses/by/ $4.0 /)$.
1 Maestría en Ciencias en Horticultura, Universidad Autónoma Agraria Antonio Narro, Saltillo 25315, CH, Mexico; juansancheznavarro@uadec.edu.mx

2 Departamento de Botánica, Universidad Autónoma Agraria Antonio Narro, Saltillo 25315, CH, Mexico; yolanda_glezg@hotmail.com

3 Departamento de Horticultura, Universidad Autónoma Agraria Antonio Narro, Saltillo 25315, CH, Mexico; abenmen@gmail.com

4 Centro de Investigación y Estudios Avanzados del Instituto Politécnico Nacional Unidad Saltillo, Ramos Arizpe 25900, CH, Mexico; america.morales@cinvestav.edu.mx

5 Cátedras CONACYT-Departamento de Horticultura, Universidad Autónoma Agraria Antonio Narro, Saltillo 25315, CH, Mexico; qfb_sgm@hotmail.com

6 Centro de Investigación en Química Aplicada, Saltillo 25294, CH, Mexico; gregorio.cadenas@ciqa.edu.mx

7 Analytical Chemistry Laboratory, Cinvestav-Saltillo, Ramos Arizpe 25900, CH, Mexico; socorro.garcia@cinvestav.edu.mx

* Correspondence: antonio.juarez@uaaan.edu.mx

\begin{abstract}
The production of ornamentals is an economic activity of great interest, particularly the production of Lilium. This plant is very attractive for its color and shapes; however, the quality of its flower and its shelf life can decrease very fast. Therefore, it is of the utmost importance to develop techniques that allow for increasing both flower quality and shelf life. Nanotechnology has allowed for the use of various materials with unique characteristics. These materials can induce a series of positive responses in plants, among which the production of antioxidant compounds stands out. The objective of this study was to determine the impact of the application of silicone nanoparticles $\left(\mathrm{SiO}_{2}\right.$ NPs) on the quality, shelf life, and antioxidant status of Lilium. For this, different concentrations of $\mathrm{SiO}_{2} \mathrm{NPs}\left(0,200,400,600,800\right.$, and $\left.1000 \mathrm{mg} \mathrm{L}^{-1}\right)$ were applied in two ways, foliar and soil, as two independent experiments. The contents of enzymatic (superoxide dismutase, glutathione peroxidase, catalase, ascorbate peroxidase, and phenylalanine ammonia lyase) and non-enzymatic (phenols, flavonoids, and glutathione) antioxidant compounds, the mineral content, flower quality, and shelf life were analyzed. The results showed that the application of $\mathrm{SiO}_{2} \mathrm{NPs}$ through the foliar method induced a greater flowers' shelf life (up to $21.62 \%$ more than the control); greater contents of $\mathrm{Mg}, \mathrm{P}$, and $\mathrm{S}$ (up to $25.6 \%, 69.1 \%$, and $113.9 \%$, respectively, compared to the control); more photosynthetic pigment (up to $65.17 \%$ of total chlorophyll); more glutathione peroxidase activity (up to $69.9 \%$ ); more phenols (up to $25.93 \%$ ); and greater antioxidant capacity as evaluated by the DPPH method (up to $5.18 \%$ ). The use of $\mathrm{SiO}_{2} \mathrm{NPs}$ in the production of Lilium is a good alternative method to increase flower quality and shelf life.
\end{abstract}

Keywords: nanotechnology; enzymatic and non-enzymatic antioxidants; ornamentals; flower quality

\section{Introduction}

The lily is a perennial herbaceous bulbous plant belonging to the genus Lilium and the family Liliaceae that is native to China and widely cultivated as an ornamental pot, garden, and cut plant $[1,2]$. It is also used in the pharmaceutical industry and gastronomy in Asia, Europe, and America [2]. This genus is among the most internationally commercialized flower crops [3]. Its form of propagation is generally by means of bulbs, although some 
species are also propagated by seeds. Its development is divided into four phases: the elongation of the shoots after sowing, beginning of the flower of the apical meristem, flowering, and senescence after flowering [4].

Maintaining flower quality and prolonging shelf life are of great importance, since longevity and quality are economically important factors for lilies' commercialization due to their short shelf life before or after harvest and deterioration, which cause difficulties for long-distance transport and a decrease in market value [5]. Senescence and poor flower quality are the main reasons for the short shelf life, which is mainly associated with an increase in lipid peroxidation and modifications of the cell wall. It is also due to other factors, such as increases in respiration and activities of hydrolytic enzymes, changes in various cell organelles, the degradation of macromolecules, microbial activities, production and sensitivity to ethylene and other hormones, and oxidative stress by reactive oxygen species (ROS) [6,7].

To overcome these problems, several postharvest technologies have been developed for the global flower industry, many of which involve the use of chemicals to inhibit the synthesis of hormones in the petals or microbial growth in the vessels of the xylem [8]. However, in the last decade, nanotechnology has developed enough to allow for its use in the agricultural industry, where it has proven its effectiveness in increasing production and reducing post-harvest losses, thus leading to a steady increase in application [3].

Silicon is considered a beneficial element for plants, although it is not essential. Moreover, its use has been reported to mitigate different types of stress in plants, mainly due to its accumulation in different plant tissues and the modification of metabolism [9]. In addition, silicon has been shown to be efficient in improving the antioxidant defense systems of plants when they are under conditions of some type of stress [10]. At the nanoscale, silicon may be more efficient at inducing responses in plants due to the new properties of materials at this scale. Therefore, studying the responses of plants with this technology is of great interest.

Silicon nanoparticles ( $\left.\mathrm{SiO}_{2} \mathrm{NPs}\right)$ have positive effects on the growth, physiology, and protection of plants, since they can significantly improve the processes of water absorption and nutrient supply; positively regulate the processes of photosynthesis and gas exchange; and activate metabolic processes, thus improving the antioxidant defense system and nitrogen metabolism [11,12]. Another positive impact of the application of $\mathrm{SiO}_{2} \mathrm{NPs}$ is the mitigation of the negative effect of stress by UV radiation, metal toxicity, saline stress, and biotic stress [9]. $\mathrm{SiO}_{2} \mathrm{NPs}$ can also directly serve as nano-pesticides, nano-herbicides, and nano-fertilizers [13].

The objective of this study was to determine the impact of the application of $\mathrm{SiO}_{2} \mathrm{NPs}$ in Lilium plants-specifically, to determine the best way to apply $\mathrm{SiO}_{2} \mathrm{NPs}$, as well as the most suitable concentration to improve flower quality and shelf life.

\section{Results}

\subsection{Flower Characteristics}

No differences were observed in stem diameter following the application of $\mathrm{SiO}_{2}$ NPs via the soil application method. However, following the foliar application of $\mathrm{SiO}_{2}$ NPs, the stem diameter was increased by $19.60 \%$ and $6.44 \%$ compared to the control with concentrations of 600 and $1000 \mathrm{mg} \mathrm{L}^{-1}$, respectively (Figure 1A).

No differences in petiole diameter were observed between treatments when the $\mathrm{SiO}_{2}$ NPs were applied by the soil method. However, the foliar application of $\mathrm{SiO}_{2} \mathrm{NPs}$ induced increases of $28.71 \%$ and $23.58 \%$ with concentrations of 600 and $1000 \mathrm{mg} \mathrm{L}^{-1}$, respectively, compared to the control (Figure 1B).

No differences were observed in the length of the flower bud following application via the soil method. However, with the foliar method, concentrations of 600 and $1000 \mathrm{mg} \mathrm{L}^{-1}$ of $\mathrm{SiO}_{2} \mathrm{NPs}$ showed increases of $27.77 \%$ and $30.27 \%$, respectively, compared to the control (Figure 1C). 

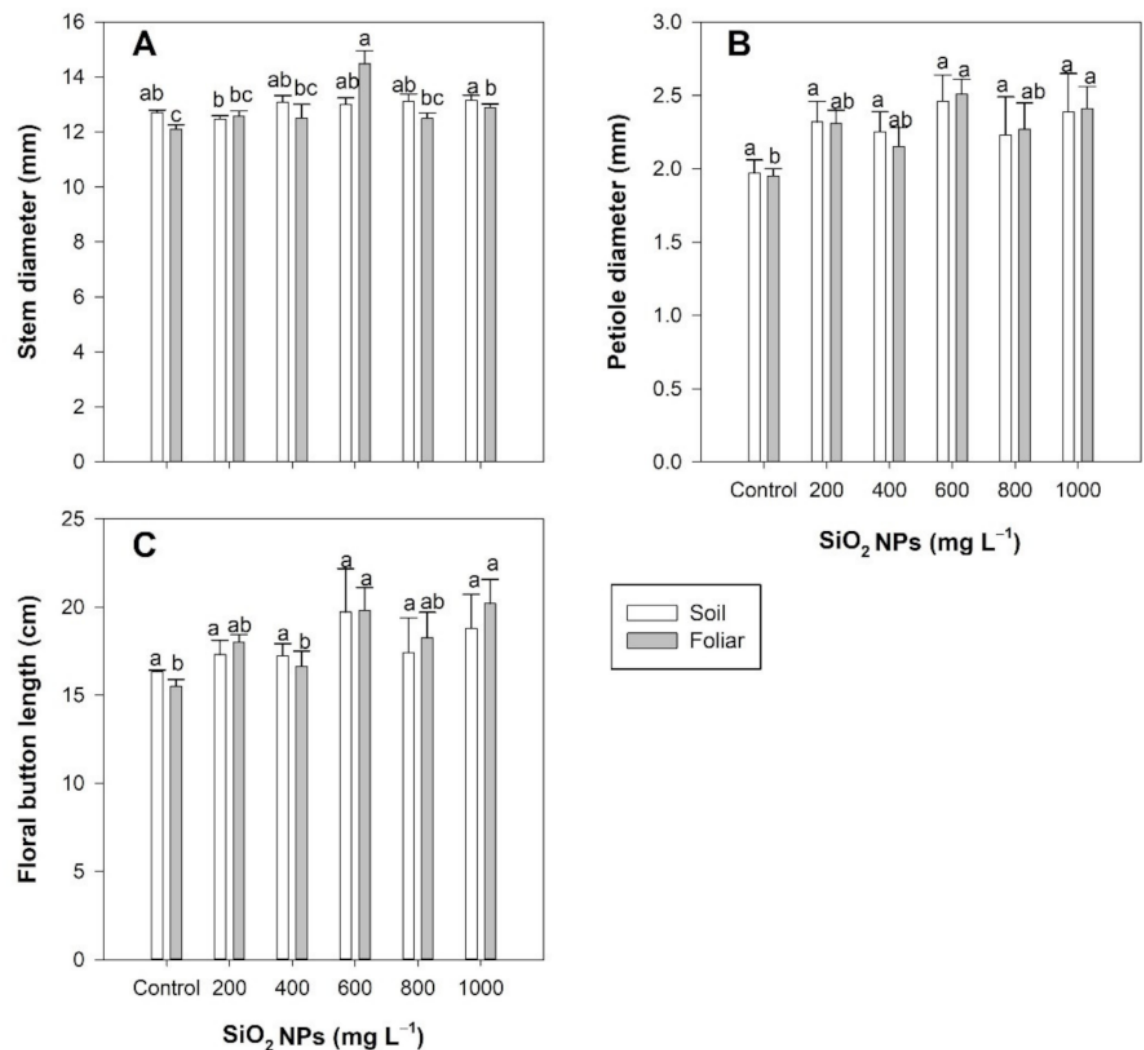

$\mathrm{SiO}_{2} \mathrm{NPs}\left(\mathrm{mg} \mathrm{L}^{-1}\right)$

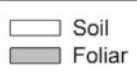

Figure 1. Effect of the application of $\mathrm{SiO}_{2} \mathrm{NPs}$ on the stem diameter (A), petiole diameter (B), and button length $(\mathbf{C})$ of Lilium plants. Different letters indicate significant differences according to Fisher's least significant difference test $(p \leq 0.05)$.

The opening of the flower bud and the flowers' shelf life behaved statistically the same when treatments were applied via the soil method. In contrast, when applied via the foliar method, the opening of the flower bud was faster at the concentration of $600 \mathrm{mg} \mathrm{L}^{-1}$, although the difference was not significant compared to the control (Figure 2A). The flowers' shelf life was increased by up to $21.62 \%$ more than the control with the application of $600 \mathrm{mg} \mathrm{L}^{-1}$ of $\mathrm{SiO}_{2} \mathrm{NPs}$ (Figure 2B).
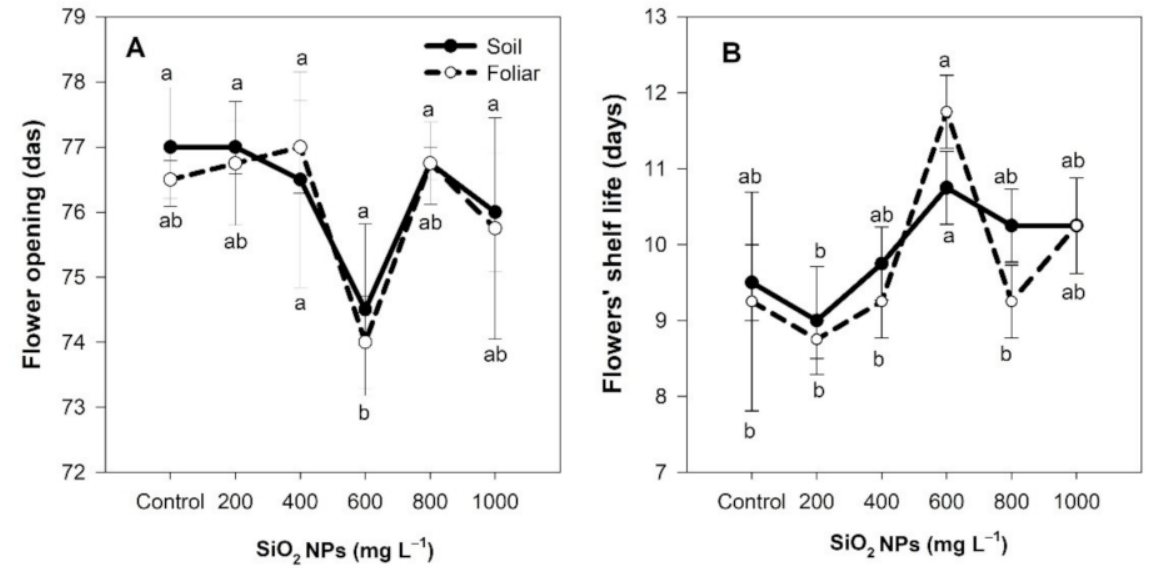

Figure 2. Effect of the application of $\mathrm{SiO}_{2} \mathrm{NPs}$ on the opening of the flower bud (A) and the flowers' shelf life (B). Different letters indicate significant differences according to Fisher's least significant difference test $(p \leq 0.05)$. das, days after sowing; days, the time (in days) for which the flowers were of good quality. 


\subsection{Accumulation of Macro- and Micronutrients}

The application of $\mathrm{SiO}_{2} \mathrm{NPs}$ via the soil method modified the concentration of some macronutrients in the leaves, such as $\mathrm{Mg}, \mathrm{P}$, and S; however, it had no effect on the macronutrient content in the flowers (Table 1). Consistently, a concentration of $600 \mathrm{mg} \mathrm{L}^{-1}$ of $\mathrm{SiO}_{2} \mathrm{NPs}$ increased the content of $\mathrm{Mg}$, $\mathrm{P}$, and $\mathrm{S}$ by $25.6 \%, 69.1 \%$, and $113.9 \%$, respectively, compared to the control.

Table 1. Effect of the application of $\mathrm{SiO}_{2} \mathrm{NPs}$ on the concentration of macronutrients in leaves and flowers.

\begin{tabular}{|c|c|c|c|c|c|c|c|c|c|}
\hline & \multirow[b]{2}{*}{ Treatment } & \multicolumn{4}{|c|}{ Leaves } & \multicolumn{4}{|c|}{ Flowers } \\
\hline & & $\mathrm{Ca}$ & $\mathrm{Mg}$ & $\mathbf{P}$ & $S$ & $\mathrm{Ca}$ & $\mathrm{Mg}$ & $\mathbf{P}$ & $S$ \\
\hline हี & $\begin{array}{c}\text { Control } \\
200 \\
400 \\
600 \\
800 \\
1000 \\
p \text {-value }\end{array}$ & $\begin{array}{c}1.04 \pm 0.09 \mathrm{a} \\
0.67 \pm 0.36 \mathrm{a} \\
0.68 \pm 0.14 \mathrm{a} \\
0.78 \pm 0.23 \mathrm{a} \\
0.58 \pm 0.05 \mathrm{a} \\
0.56 \pm 0.13 \mathrm{a} \\
\text { NS }\end{array}$ & $\begin{array}{c}1.60 \pm 0.11 \mathrm{bc} \\
1.49 \pm 0.09 \mathrm{c} \\
1.89 \pm 0.08 \mathrm{ab} \\
2.01 \pm 0.07 \mathrm{a} \\
1.59 \pm 0.14 \mathrm{c} \\
1.78 \pm 0.09 \mathrm{abc} \\
0.0125\end{array}$ & $\begin{array}{c}2.30 \pm 0.08 \mathrm{c} \\
2.98 \pm 0.24 \mathrm{bc} \\
3.43 \pm 0.07 \mathrm{ab} \\
3.89 \pm 0.27 \mathrm{a} \\
3.11 \pm 0.40 \mathrm{~b} \\
3.46 \pm 0.16 \mathrm{ab} \\
0.0033\end{array}$ & $\begin{array}{c}0.77 \pm 0.06 \mathrm{~d} \\
0.90 \pm 0.13 \mathrm{~cd} \\
1.26 \pm 0.05 \mathrm{~b} \\
1.64 \pm 0.06 \mathrm{a} \\
1.10 \pm 0.14 \mathrm{bc} \\
1.33 \pm 0.09 \mathrm{~b} \\
0.0010\end{array}$ & $\begin{array}{c}12.39 \pm 0.61 \mathrm{a} \\
13.94 \pm 0.50 \mathrm{a} \\
13.59 \pm 1.21 \mathrm{a} \\
15.23 \pm 1.12 \mathrm{a} \\
11.99 \pm 1.78 \mathrm{a} \\
12.78 \pm 1.56 \mathrm{a} \\
\text { NS }\end{array}$ & $\begin{array}{l}4.70 \pm 0.21 \mathrm{a} \\
4.24 \pm 0.07 \mathrm{a} \\
4.20 \pm 0.30 \mathrm{a} \\
4.27 \pm 0.20 \mathrm{a} \\
3.76 \pm 0.41 \mathrm{a} \\
4.33 \pm 0.55 \mathrm{a} \\
\mathrm{NS}\end{array}$ & $\begin{array}{c}2.79 \pm 0.17 \mathrm{a} \\
3.52 \pm 0.29 \mathrm{a} \\
3.32 \pm 0.13 \mathrm{a} \\
3.18 \pm 0.30 \mathrm{a} \\
3.18 \pm 0.34 \mathrm{a} \\
3.05 \pm 0.43 \mathrm{a} \\
\mathrm{NS}\end{array}$ & $\begin{array}{c}1.33 \pm 0.06 \mathrm{a} \\
1.61 \pm 0.06 \mathrm{a} \\
1.55 \pm 0.06 \mathrm{a} \\
1.69 \pm 0.21 \mathrm{a} \\
1.48 \pm 0.19 \mathrm{a} \\
1.53 \pm 0.15 \mathrm{a} \\
\mathrm{NS}\end{array}$ \\
\hline \multirow{3}{*}{.ี్ّี } & $\begin{array}{l}\text { Control } \\
200 \\
400\end{array}$ & $\begin{array}{l}1.08 \pm 0.21 \mathrm{a} \\
0.80 \pm 0.17 \mathrm{a} \\
0.47 \pm 0.06 \mathrm{a}\end{array}$ & $\begin{array}{l}1.91 \pm 0.16 \mathrm{a} \\
1.89 \pm 0.07 \mathrm{a} \\
1.85 \pm 0.07 \mathrm{a}\end{array}$ & $\begin{array}{l}3.68 \pm 0.33 \mathrm{a} \\
3.27 \pm 0.10 \mathrm{a} \\
3.59 \pm 0.16 \mathrm{a}\end{array}$ & $\begin{array}{l}1.32 \pm 0.13 \mathrm{a} \\
1.26 \pm 0.02 \mathrm{a} \\
1.24 \pm 0.03 \mathrm{a}\end{array}$ & $\begin{array}{c}9.72 \pm 1.56 \mathrm{c} \\
14.2 \pm 0.51 \mathrm{ab} \\
15.2 \pm 0.82 \mathrm{a}\end{array}$ & $\begin{array}{l}3.74 \pm 0.67 \mathrm{a} \\
4.67 \pm 0.20 \mathrm{a} \\
4.89 \pm 0.23 \mathrm{a}\end{array}$ & $\begin{array}{l}2.75 \pm 0.17 \mathrm{a} \\
2.85 \pm 0.35 \mathrm{a} \\
3.45 \pm 0.26 \mathrm{a}\end{array}$ & $\begin{array}{l}1.09 \pm 0.19 a \\
1.44 \pm 0.08 \mathrm{a} \\
1.54 \pm 0.06 \mathrm{a}\end{array}$ \\
\hline & 600 & $0.72 \pm 0.18 \mathrm{a}$ & $1.86 \pm 0.24 \mathrm{a}$ & $3.52 \pm 0.38 \mathrm{a}$ & $1.20 \pm 0.11 \mathrm{a}$ & $\begin{array}{c}12.53 \pm 1.49 \\
\mathrm{abc}\end{array}$ & $4.24 \pm 0.50 \mathrm{a}$ & $2.83 \pm 0.33 \mathrm{a}$ & $1.37 \pm 0.22 \mathrm{a}$ \\
\hline & $\begin{array}{c}800 \\
1000 \\
p \text {-value }\end{array}$ & $\begin{array}{c}0.91 \pm 0.12 \mathrm{a} \\
0.99 \pm 0.22 \mathrm{a} \\
\text { NS }\end{array}$ & $\begin{array}{c}1.71 \pm 0.05 \mathrm{a} \\
1.89 \pm 0.07 \mathrm{a} \\
\text { NS }\end{array}$ & $\begin{array}{c}3.28 \pm 0.23 \mathrm{a} \\
3.48 \pm 0.33 \mathrm{a} \\
\text { NS }\end{array}$ & $\begin{array}{c}1.28 \pm 0.07 \mathrm{a} \\
1.40 \pm 0.06 \mathrm{a} \\
\text { NS }\end{array}$ & $\begin{array}{c}13.91 \pm 0.87 \mathrm{ab} \\
11.13 \pm 1.21 \mathrm{bc} \\
0.0280\end{array}$ & $\begin{array}{c}4.81 \pm 0.30 \mathrm{a} \\
3.79 \pm 0.30 \mathrm{a} \\
\text { NS }\end{array}$ & $\begin{array}{c}3.35 \pm 0.22 \mathrm{a} \\
2.92 \pm 0.15 \mathrm{a} \\
\text { NS }\end{array}$ & $\begin{array}{c}1.62 \pm 0.14 \mathrm{a} \\
1.41 \pm 0.07 \mathrm{a} \\
\text { NS }\end{array}$ \\
\hline
\end{tabular}

Different letters per column indicate significant differences according to Fisher's least significant difference test $(p \leq 0.05)$. $n=4 \pm$ standard error.

Following the application of $\mathrm{SiO}_{2} \mathrm{NPs}$ via the foliar method, only the calcium content in the flower was modified; the highest concentration, $56.4 \%$ more than the control, was observed with $400 \mathrm{mg} \mathrm{L}^{-1}$ of $\mathrm{SiO}_{2}$ NPs (Table 1).

Regarding micronutrient contents, the application of $\mathrm{SiO}_{2} \mathrm{NPs}$ via the soil method in concentrations of 600 and $800 \mathrm{mg} \mathrm{L}^{-1}$ increased the content of $\mathrm{Zn}$ in the leaves by approximately $64 \%$ compared to the control. In contrast, the copper content in the flowers

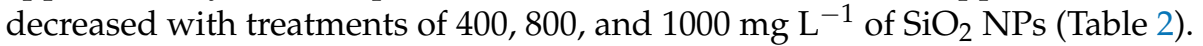

The foliar application of $\mathrm{SiO}_{2}$ NPs only modified the $\mathrm{Zn}$ content in the flowers, as the $400 \mathrm{mg} \mathrm{L}^{-1}$ treatment increased the content of this element by $34.1 \%$ compared to the control (Table 2).

\subsection{Photosynthetic Pigments}

The chlorophyll content in the Lilium flowers exposed to different concentrations of $\mathrm{SiO}_{2}$ NPs did not show differences between treatments; however, a clear increasing trend was observed with $800 \mathrm{mg} \mathrm{L}^{-1}$ of $\mathrm{SiO}_{2} \mathrm{NPs}$ when the application was carried out via the soil method (Figure 3A). When $\mathrm{SiO}_{2} \mathrm{NPs}$ were applied through the foliar method, the chlorophyll $a$ content increased in the flowers by $19.67 \%$ and $18.03 \%$ and the total chlorophyll increased by $12.20 \%$ and $10.81 \%$ with concentrations of 800 and $1000 \mathrm{mg} \mathrm{L}^{-1}$, respectively (Figure 3B). 
Table 2. Effect of the application of $\mathrm{SiO}_{2} \mathrm{NPs}$ on the concentration of micronutrients in leaves and flowers.

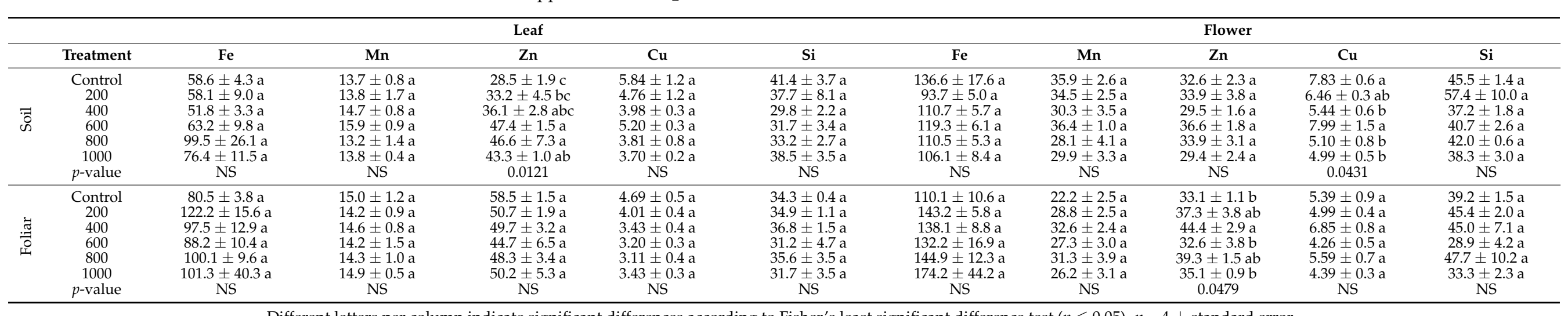

Different letters per column indicate significant differences according to Fisher's least significant difference test $(p \leq 0.05) . n=4 \pm$ standard error. 

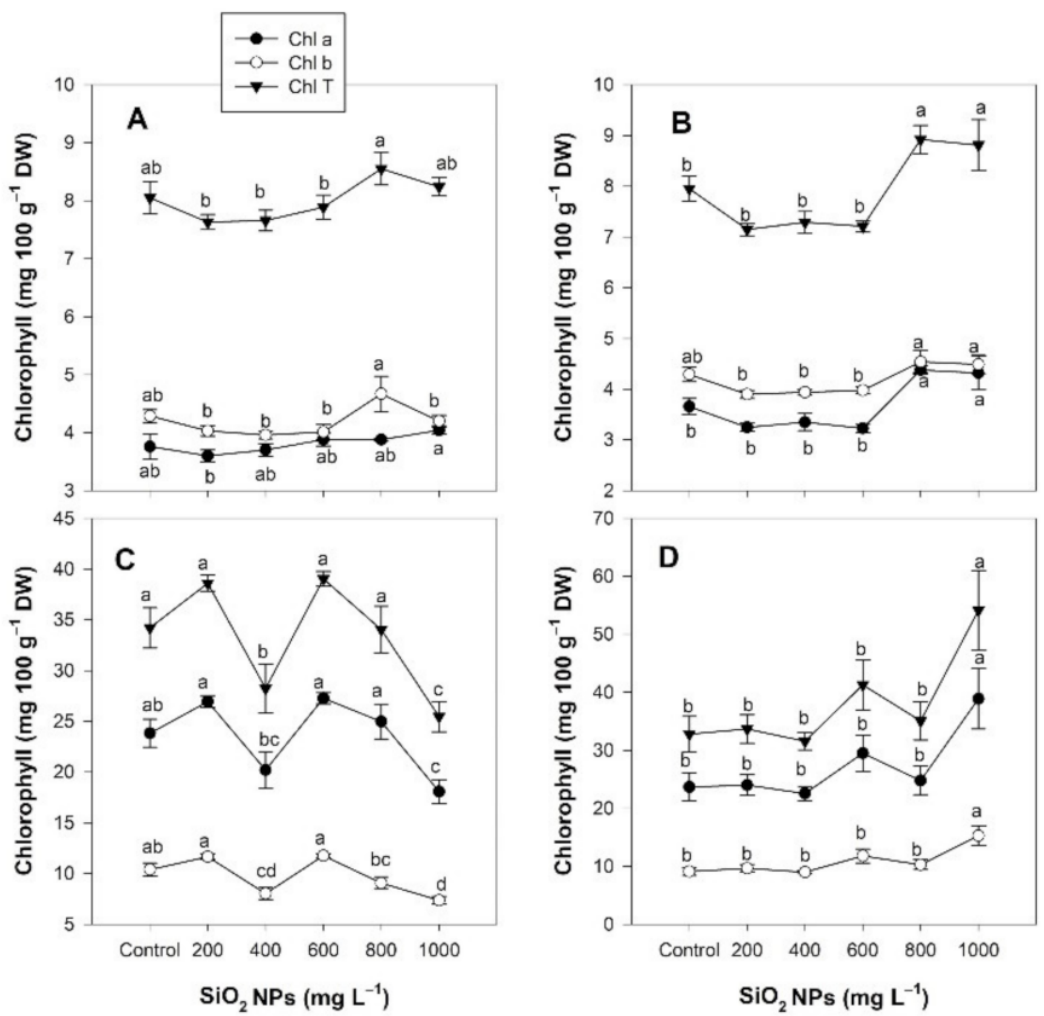

Figure 3. Effect of the application of $\mathrm{SiO}_{2}$ NPs via the soil method $(\mathrm{A}, \mathrm{C})$ and the foliar method $(\mathbf{B}, \mathbf{D})$ on the concentration of chlorophyll in the flowers $(\mathbf{A}, \mathbf{B})$ and leaves $(\mathbf{C}, \mathbf{D})$ of Lilium. Different letters indicate significant differences according to Fisher's least significant difference test $(p \leq 0.05)$.

In the leaves, the chlorophyll content decreased following the application of $\mathrm{SiO}_{2}$ NPs when they were applied to the soil; chlorophyll $a$ decreased by $24.09 \%$, chlorophyll $b$ decreased by $29.07 \%$, and total chlorophyll decreased by $25.57 \%$ at a concentration of $1000 \mathrm{mg} \mathrm{L}^{-1}$ (Figure 3C). Meanwhile, foliar application induced increases in chlorophyll at a concentration of $1000 \mathrm{mg} \mathrm{L}^{-1}$ of $\mathrm{SiO}_{2}$ NPs: $64.25 \%$ in chlorophyll $a, 67.54 \%$ in chlorophyll $b$, and $65.17 \%$ in total chlorophyll (Figure 3D).

\subsection{Antioxidant Enzymes}

The application of $\mathrm{SiO}_{2} \mathrm{NPs}$ via the soil method did not modify the activity of superoxide dismutase (SOD) in the leaves compared to the control; only a decrease in the activity of this enzyme was observed ay a concentration of $600 \mathrm{mg} \mathrm{L}^{-1}$ in the flowers (Figure 4A). In the case of foliar application, the activity of this enzyme in the flowers was not modified by the application of $\mathrm{SiO}_{2} \mathrm{NPs}$; however, an increase of $6.21 \%$ was observed in the leaves ay a concentration of $800 \mathrm{mg} \mathrm{L}^{-1}$ (Figure $4 \mathrm{~B}$ ).

The glutathione peroxidase (GPX) activity in the leaves decreased by $39.85 \%$ and $43.27 \%$ ay concentrations of 400 and $600 \mathrm{mg} \mathrm{L}^{-1}$, respectively, compared to the control when the $\mathrm{SiO}_{2} \mathrm{NPs}$ were applied via the soil. In the flowers, the GPX activity also decreased by $39.7 \%$, at a concentration of $400 \mathrm{mg} \mathrm{L}^{-1}$ (Figure $4 \mathrm{C}$ ). Following application through the foliar method, the activity of GPX in the leaves did not show differences between treatments. In contrast, GPX activity increased by $69.9 \%$ in the flowers at a concentration of $1000 \mathrm{mg} \mathrm{L}^{-1}$ of $\mathrm{SiO}_{2}$ NPs compared to the control (Figure 4D).

The catalase (CAT) activity did not show differences between treatments or application methods in either of the two evaluated organs (Figure 4E,F).

The ascorbate peroxidase (APX) activity was not modified when the treatment was applied to the soil, neither in the leaves nor in the flowers (Figure 4G). When the application was through the foliar method, the activity of APX in the leaves decreased in all treatments, while there were no differences between the treatments in the flowers (Figure $4 \mathrm{H}$ ). 

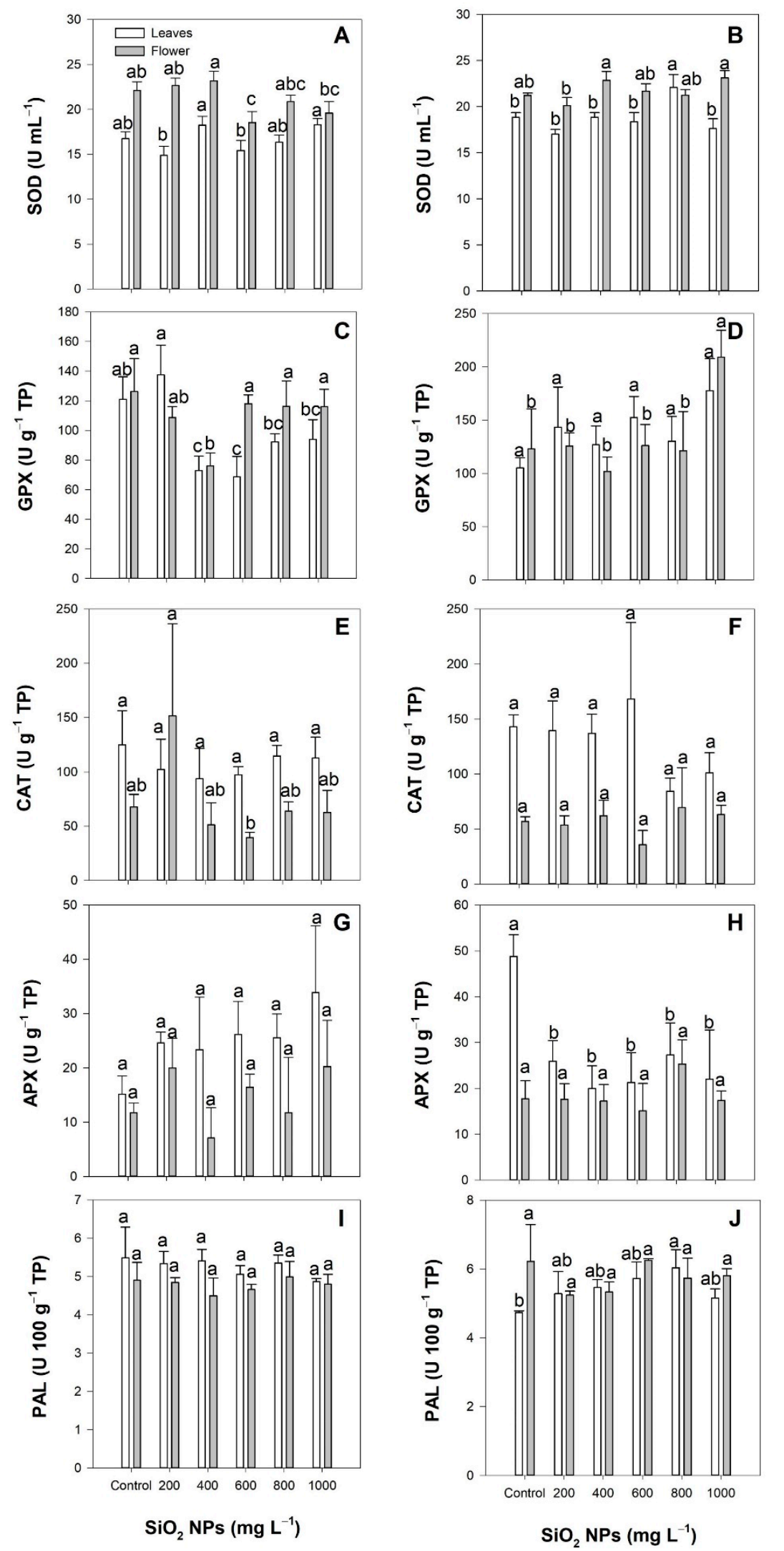

Figure 4. Effect of the application of $\mathrm{SiO}_{2} \mathrm{NPs}$ via the soil method $(\mathrm{A}, \mathrm{C}, \mathrm{E}, \mathrm{G}, \mathrm{I})$ and the foliar method $(\mathbf{B}, \mathbf{D}, \mathbf{F}, \mathbf{H}, \mathbf{J})$ on the activity of the antioxidant enzymes SOD $(\mathbf{A}, \mathbf{B}), \operatorname{GPX}(\mathbf{C}, \mathbf{D}), \mathrm{CAT}(\mathbf{E}, \mathbf{F}), \mathrm{APX}(\mathbf{G}, \mathbf{H})$, and PAL $(\mathbf{I}, \mathbf{J})$ in Lilium. Different letters indicate significant differences according to Fisher's least significant difference test $(p \leq 0.05)$. 
The phenylalanine ammonia lyase (PAL) enzymatic activity did not show differences between treatments, neither in the leaves nor in the flowers, following the application of $\mathrm{SiO}_{2} \mathrm{NPs}$ via the soil method (Figure $4 \mathrm{I}$ ). In contrast, the foliar application of $800 \mathrm{mg} \mathrm{L}^{-1}$ of $\mathrm{SiO}_{2} \mathrm{NPs}$ increased the PAL activity in the leaves by $27.48 \%$, while there were no differences between the treatments in the flowers (Figure 4J).

\subsection{Non-Enzymatic Antioxidant Compounds}

The phenol content did not show differences between the treatments compared to the control when the $\mathrm{SiO}_{2} \mathrm{NPs}$ were applied via the soil method in any of the evaluated organs (Figure 5A). When the $\mathrm{SiO}_{2} \mathrm{NPs}$ were applied via through the foliar method at a concentration of $1000 \mathrm{mg} \mathrm{L}^{-1}$, the content of phenols in the leaves increased by $25.93 \%$; however, there were no differences between the treatments in the flowers (Figure 5B).
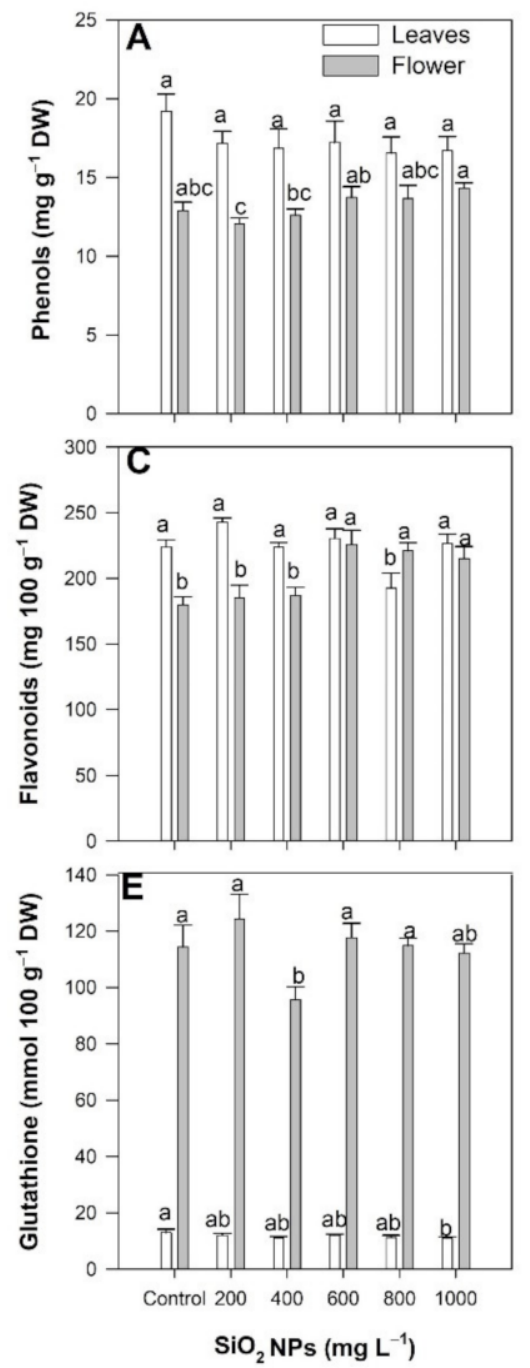
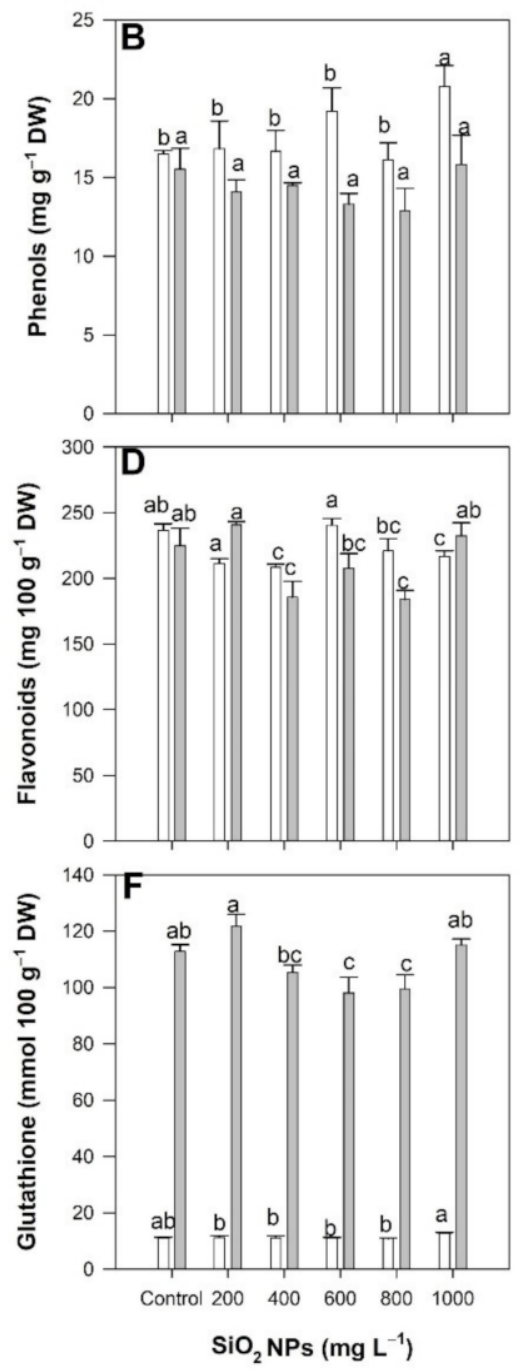

Figure 5. Effect of the application of $\mathrm{SiO}_{2}$ NPs via the soil method $(\mathbf{A}, \mathbf{C}, \mathbf{E})$ and the foliar method $(\mathbf{B}, \mathbf{D}, \mathbf{F})$ on the non-enzymatic antioxidants: phenols $(\mathbf{A}, \mathbf{B})$, flavonoids $(\mathbf{C}, \mathbf{D})$, and glutathione $(\mathbf{E}, \mathbf{F})$. Different letters indicate significant differences according to Fisher's least significant difference test $(p \leq 0.05)$.

Following application via the soil method, the flavonoid content in the leaves did not show differences between treatments. However, there were increases of $25.65 \%, 23.02 \%$, and $19.64 \%$ in the flowers at concentrations of 600,800 , and $1000 \mathrm{mg} \mathrm{L}^{-1}$ of $\mathrm{SiO}_{2} \mathrm{NPs}$, respectively, compared to the control (Figure 5C). In contrast, following the foliar application of $\mathrm{SiO}_{2} \mathrm{NPs}$, the flavonoid content in the leaves decreased by $10.59 \%, 11.86 \%$, and 
$8.47 \%$ at 200,400 , and $800 \mathrm{mg} \mathrm{L}^{-1}$ of $\mathrm{SiO}_{2} \mathrm{NPs}$, respectively. The flavonoid content in the flowers decreased $17.50 \%$ and $18.25 \%$ at $\mathrm{SiO}_{2} \mathrm{NP}$ concentrations of 400 and $800 \mathrm{mg} \mathrm{L}^{-1}$, respectively (Figure 5D).

The glutathione content in the leaves decreased by $16 \%$ with $1000 \mathrm{mg} \mathrm{L}^{-1}$ of $\mathrm{SiO}_{2}$ NPs applied via the soil method, and in the flowers, it decreased by $16.67 \%$ with the application of $400 \mathrm{mg} \mathrm{L}^{-1}$ (Figure 5E). Following foliar application, we observed decreases in glutathione of $13.07 \%$ and $11.72 \%$ in the flowers at 600 and $800 \mathrm{mg} \mathrm{L}^{-1}$ of $\mathrm{SiO}_{2} \mathrm{NPs}$, respectively; meanwhile, there were no differences between treatments in the leaves (Figure 5F).

\subsection{Antioxidant Capacity}

As evaluated with the 2,2-diphenyl-1-picrylhydrazyl (DPPH) radical, the total antioxidant capacity increased by $6.43 \%$ in the leaves following the soil application of $400 \mathrm{mg} \mathrm{L}^{-1}$ of $\mathrm{SiO}_{2} \mathrm{NPs}$ due to the $10.21 \%$ increase in the antioxidant capacity of the hydrophilic compounds (Figure 6A). In contrast, a decrease of $9.27 \%$ in the antioxidant capacity of hydrophilic compounds was observed in the flowers at $800 \mathrm{mg} \mathrm{L}^{-1}$ of $\mathrm{SiO}_{2} \mathrm{NPs}$ (Figure 6B).
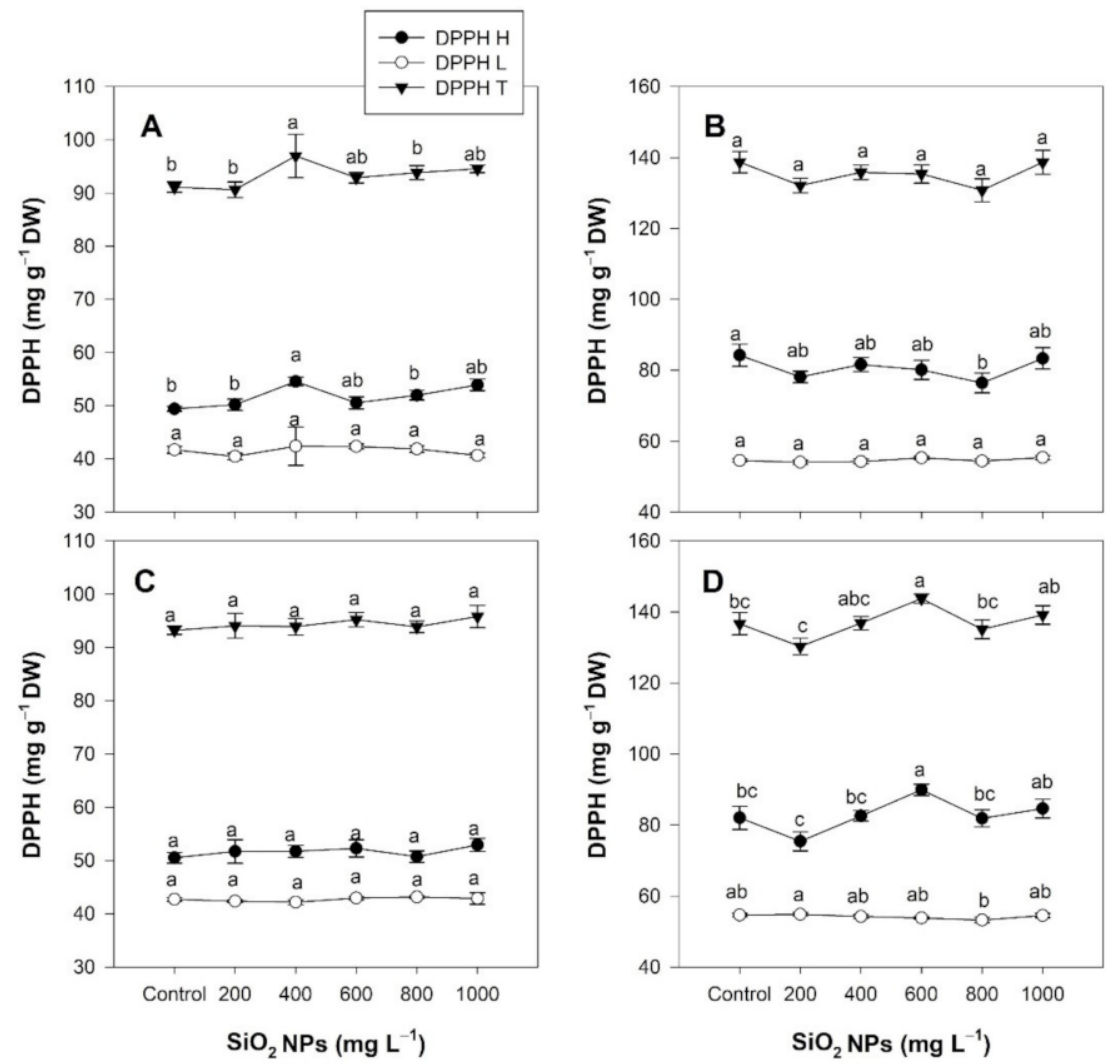

Figure 6. Effect of the application of $\mathrm{SiO}_{2} \mathrm{NPs}$ via the soil method $(\mathrm{A}, \mathrm{C})$ and the foliar method $(\mathbf{B}, \mathbf{D})$ on the antioxidant capacity in the leaves $(\mathbf{A}, \mathbf{B})$ and flowers $(\mathbf{C}, \mathbf{D})$ of Lilium plants. DPPH H: antioxidant capacity of the hydrophilic compounds. DPPH L: antioxidant capacity of the lipophilic compounds. DPPH T: total antioxidant capacity. Different letters indicate significant differences according to Fisher's least significant difference test $(p \leq 0.05)$.

Following foliar application, the antioxidant capacity in the leaves was not modified by the $\mathrm{SiO}_{2} \mathrm{NPs}$ (Figure 6C). In contrast, the foliar application of $\mathrm{SiO}_{2} \mathrm{NPs}$ increased the antioxidant capacity of the flowers by $5.18 \%$ at a concentration of $600 \mathrm{mg} \mathrm{L}^{-1}$ due to the $9.53 \%$ increase in the antioxidant capacity of the hydrophilic compounds compared to the control (Figure 6D). 


\section{Discussion}

During their development and maturation, flowers require nutrients to keep their metabolism optimal. However, when metabolism is affected, the release of amino acids and monosaccharides from the cell wall can be promoted, since ATP is obtained from them. This leads to the degradation of cell walls and, consequently, to decreases in the life and quality of flowers. Additionally, damage to membranes causes the production of ROS, which results in lipid peroxidation and, ultimately, the senescence of plants [14]. Particularly in the case of cut flowers, senescence is closely linked to the lipid peroxidation of the petals [15]. Thus, an adequate availability of carbohydrates improves the shelf life by acting as a source of energy and nutrition, especially for flower stems with developing buds [16].

Oxidative stress is one of the most important factors that affects both the life of flowers and the quality of cut flowers. Oxidative stress affects cell mechanisms and membrane lipids, accelerating senescence, which is why avoiding or reducing oxidative stress is crucial to increasing the lifespan of flowers [17]. Therefore, an adequate antioxidant defense system can increase the shelf life of flowers, as observed in this study of the application of $\mathrm{SiO}_{2} \mathrm{NPs}$.

It has been widely documented that various nanomaterials (NMs) can induce positive responses (such as better growth and development) and changes in metabolism in plants, which can help tolerate different stress conditions [18-23]. Nanomaterials have unique properties, including a high surface/volume ratio that results in a high surface energy of these materials; this makes them more reactive, and they can impact plants in different ways when interacting [24]. Interactions can occur from the moment NMs come into contact with a cell, i.e., the cell wall and cell membrane, where a series of signals and changes are produced in the transport of metabolites and ions, as well as the production of ROS; additionally, when they enter the cell, they also interact with different organelles and induce oxidative stress. The results of these interactions can be positive, negative, or null for plants, and they are highly dependent on the amount and type of NMs [25].

NMs activate the antioxidant defense system, and the synthesis of enzymatic and non-enzymatic antioxidant compounds is increased [18-20]. The ability of NMs to modify the antioxidant system of plants is one of their main effects, and it is related to the ability to tolerate stress [21]. However, they also have the ability to modify secondary metabolism and, therefore, the synthesis of secondary metabolites such as phenols and flavonoids [22,23].

Silicon is one of the elements that is considered beneficial for plants; when applied, it induces a series of beneficial responses, such as greater growth and development, as well as tolerance to different conditions of both biotic and abiotic stress [26-28]. One of the characteristics of silicon that can influence shelf life is that once it penetrates and moves through a plant, it is deposited in the structures where transpiration occurs and becomes insoluble crystals [29]. This makes the cell walls stiffer and, therefore, more durable over time, and it can reduce degradation and extend the shelf life of flowers. In the form of NPs, silicon can increase its ability to induce these effects due to the unique characteristics of nanoscale materials [24], as observed in the present study.

In addition, several studies have shown that the use of silicon-based NPs improves some metabolic processes in plants related to the antioxidant system and, through these, increases the synthesis of antioxidant compounds. In Dracocephalum kotschyi plants developed in an MS culture medium and with the application of $\mathrm{SiO}_{2} \mathrm{NPs}$, an increase in flavonoids (xanthomicrol, cirsimaritin, and isokaempferide) was observed. This was due to the overexpression of the phenylalanine ammonia lyase and rosmarinic acid synthase (RAS) genes that are closely linked to the rosmarinic acid biosynthetic pathway [30]. The contents of phenols, flavonoids, and tropane alkaloids (hyoscyamine and scopolamine) were also increased in Hyoscyamus reticulatus and $\mathrm{H}$. pusillus plants in which $\mathrm{SiO}_{2} \mathrm{NPs}$ were directly applied to the root. In this case, the overexpressed genes were $p m t$ (putrescine $\mathrm{N}$-methyltransferase) and h6h (hyoscyamine $6 \beta$-hydroxylase) [31]. This showed that the positive effects observed 
in the antioxidant compounds of Lilium may be related to the impact of $\mathrm{SiO}_{2} \mathrm{NPs}$ on the antioxidant defense system and the secondary metabolism of plants.

$\mathrm{SiO}_{2} \mathrm{NPs}$ can modify the uptake of nutrients in plants due to different mechanisms, such as the production of organic acids by the roots, that can ultimately facilitate nutrient uptake [32]. Particularly, citric, oxalic, and malic acids form complexes with metals, which affect the fixation, mobility, and availability of nutrients to plants [33]. Moreover, by interacting with the cell walls and membranes of a root, NPs can modify the activity of transporters [34]. Silicon has been shown to have the ability to activate $\mathrm{H}^{+}$-ATPases located in the plasma membrane and increase the uptake of potassium through electrochemical gradients, $\mathrm{K}^{+}$channels, and transporters [35].

Le et al. [36] reported a decrease in the concentrations of $\mathrm{Cu}$ and $\mathrm{Mg}$ in shoots of Bt-transgenic cotton following the application of $\mathrm{SiO}_{2} \mathrm{NPs}$. González-Moscoso et al. [37] reported decreases in the Fe concentration in tomato leaves with the application of $\mathrm{SiO}_{2}$ NPs; however, they observed increases in the concentrations of $\mathrm{Cu}$ and $\mathrm{Zn}$. Tripathi et al. [38] reported increases in K and P in the roots and leaves of Pisum sativum seedlings following the addition of Si NPs. Alsaeedi et al. [39] reported increases in the uptake of K in different organs of Cucumis sativus plants following the application of Si NPs.

\section{Materials and Methods}

\subsection{Establishment of Crops}

An experiment was established under greenhouse conditions using Lilium orientalis "Oriental hybrid, cv Table Dance" plants. The transplant was carried out in $4 \mathrm{~L}$ plastic containers, with a perlite/peat moss mixture in a 1:1 ratio. A directed irrigation system and a $25 \%$ concentration Steiner nutrient solution were used [40] to provide the necessary nutrients to the plant. The $\mathrm{pH}$ of the solution was adjusted to 6.5 , and the electrical conductivity (EC) reached $1.1 \mathrm{dS} \mathrm{m}^{-1}$.

\subsection{Treatments}

The treatments consisted of suspensions of $\mathrm{SiO}_{2}$ NPs in concentrations of 200, 400, 600,800 , and $1000 \mathrm{mg} \mathrm{L}^{-1}$, in addition to a control. These treatments were selected on the basis of the results obtained by Pinedo-Guerrero et al. [41]. Moreover, the study of these authors showed that silicon at the nanoscale $\left(\mathrm{SiO}_{2} \mathrm{NPs}\right)$ is better than ionic silicon $\left(\mathrm{K}_{2} \mathrm{SiO}_{3}\right)$ at inducing positive responses in plants [41]. $\mathrm{SiO}_{2} \mathrm{NPs}$ were of $10-20 \mathrm{~nm}$ in size, had a spherical morphology, a surface area of $160 \mathrm{~m}^{2} \mathrm{~g}^{-1}$, and a bulk density of $0.08-0.1 \mathrm{~g} \mathrm{~cm}^{-3}$ (SkySpring Nanomaterials Inc., Houston, TX, USA). The application of $\mathrm{SiO}_{2}$ NPs was accomplished through two methods, one foliar and the other soil, and each application method formed an independent experiment. A total of five applications were made, starting 15 days after sowing the bulbs (das). In order to conduct an adequate comparison between both application methods, we first applied the foliar treatments and quantified the amount of $\mathrm{SiO}_{2} \mathrm{NPs}$ in solution so that we could apply the same amount $\mathrm{SiO}_{2} \mathrm{NPs}$ in solution via soil. Volumes of 2, 4, 6, 8, and $10 \mathrm{~mL}$ per plant were used at 15, 29, 43,57 , and 71 days, respectively, for both methods of application.

\subsection{Agronomic Evaluations}

To determine the effect of the treatments on the development of the plants and flowers, the diameter of the plant stems, the diameter of the flower stalks, and the size of the flowers were determined. The stem diameters were determined between the second and third leaves of the plants. The diameters of the flower stalks were determined at the junction with the flower calyx. The sizes of the flowers were determined prior to opening from the calyx to the apex of the flowers. In addition, we quantified both the days since sowing to the opening of the flower buds and the shelf life of the plants (from the opening of the first flower bud to the loss of the first flower petal). 


\subsection{Macro- and Micronutrient Determination}

The contents of macronutrients ( $\mathrm{Ca}, \mathrm{Mg}, \mathrm{P}$, and $\mathrm{S})$, micronutrients (Fe, $\mathrm{Mn}, \mathrm{Zn}$, and $\mathrm{Cu}$ ), and silicon in leaves and flowers were determined with a plasma emission spectrophotometer (Optima 8300 ICP-OES Optical System, PerkinElmer, MA, USA). For this, dry tissue of leaves and flowers ( $1 \mathrm{~g}$ of each sample) was taken and digested in $30 \mathrm{~mL}$ of nitric acid at $300{ }^{\circ} \mathrm{C}$ over a time period of $6 \mathrm{~h}$. After this, the volume of each sample was brought to $50 \mathrm{~mL}$ with deionized water for analysis.

\subsection{Biochemical Analysis}

\subsubsection{Photosynthetic Pigments}

Chlorophyll a, chlorophyll b, and total chlorophyll were determined using $0.1 \mathrm{~g}$ of lyophilized tissue to which $20 \mathrm{~mL}$ of a hexane/acetone solution (3:2) were added. These samples were centrifuged, and aliquots were taken from the supernatants and measured in a UV-vis spectrophotometer (UNICO Model UV2150, Dayton, NJ, USA) at 645 and $663 \mathrm{~nm}$. The chlorophyll concentration ( $\mathrm{mg} 100 \mathrm{~g}^{-1}$ dry weight) was calculated using the equations described by Nagata and Yamashita [42].

\subsubsection{Antioxidant Enzymes}

Prior to the analysis, we obtained an extract with which the enzymes were determined. Then, $200 \mathrm{mg}$ of previously lyophilized leaf and flower plant tissue and $20 \mathrm{mg}$ of polyvinyl pyrrolidone were used. This mixture was extracted by adding $1.5 \mathrm{~mL}$ of phosphate buffer at $\mathrm{pH} 7(0.1 \mathrm{M})$, sonicating for $5 \mathrm{~min}$, and centrifuging in a centrifuge (OHAUS Frontier Model FC5515 R, Parsippany, NJ, USA) at $17,500 \times \mathrm{g}$ for $10 \mathrm{~min}$ at $4{ }^{\circ} \mathrm{C}$. The supernatant was collected and filtered with a 0.45 micron pore PTFE membrane. Finally, it was diluted to 1:20 with phosphate buffer at $\mathrm{pH} 7(0.1 \mathrm{M})$. With this extract, we determined the different enzymes, and we determined the total protein content (TP, $\left.\mathrm{mg} \mathrm{g}^{-1} \mathrm{DW}\right)$ with Bradford's colorimetric technique [43]. In a microplate, $5 \mu \mathrm{L}$ of the extract and $250 \mu \mathrm{L}$ of the Bradford reagent were placed in each well. This mixture was incubated for $10 \mathrm{~min}$ at room temperature $\left(26^{\circ} \mathrm{C}\right)$ and then read at a $630 \mathrm{~nm}$ wavelength in a microplate reader (Allsheng, model AMR-100, Hangzhou, China). The total proteins were used to calculate the specific activity of each enzyme.

Superoxide dismutase (SOD) (EC 1.15.1.1) was evaluated out using a 706,002 SOD Cayman ${ }^{\circledR}$ Kit plus $20 \mu \mathrm{L}$ of enzymatic extract; the absorbance was measured at a length of $450 \mathrm{~nm}$ using a plate reader (Allsheng, model AMR-100, Hangzhou, China). The results are expressed as units per gram of total proteins $\left(\mathrm{U} \mathrm{mL}^{-1}\right)$, where $U$ is defined as the amount of enzyme necessary to exhibit at 50\% dismutation of the superoxide radical.

Catalase (CAT) (EC 1.11.1.6) was quantified by the spectrophotometric method used by Dhindsa et al. [44]. The measurement was carried out twice (at time 0 (T0) and at time 1 (T1)). At T0, $100 \mu \mathrm{L}$ of the enzyme extract, $400 \mu \mathrm{L}$ of $\mathrm{H}_{2} \mathrm{SO}_{4}(5 \%)$, and $1000 \mu \mathrm{L}$ of $\mathrm{H}_{2} \mathrm{O}_{2}(100$ $\mathrm{mM}$ ) were added to a test tube and mixed. Then, the absorbance was measured at $270 \mathrm{~nm}$ in a UV-vis spectrophotometer (UNICO Model UV2150, Dayton, NJ, USA) using a quartz cell. The measurement at T1 was taken after $60 \mathrm{~s}$ of reaction. The difference between $\mathrm{T} 1$ and T0 was used to obtain the activity of the enzyme. The results are expressed as $\mathrm{U} \mathrm{g}^{-1} \mathrm{TP}$, where $\mathrm{U}$ is equal to the millimole equivalent of $\mathrm{H}_{2} \mathrm{O}_{2}$ consumed per milliliter per minute.

Ascorbate peroxidase (APX) (EC 1.11.1.11) was evaluated in accordance with the method of Nakano and Asada [45]. The measurement was performed twice (at time 0 (T0) and at time 1 (T1)). At T0, a mixture of $100 \mu \mathrm{L}$ of the enzyme extract, $500 \mu \mathrm{L}$ of ascorbate $\left(10 \mathrm{mg} \mathrm{L}{ }^{-1}\right), 400 \mu \mathrm{L}$ of $\mathrm{H}_{2} \mathrm{SO}_{4}(5 \%)$, and $1000 \mu \mathrm{L}$ of $\mathrm{H}_{2} \mathrm{O}_{2}(100 \mathrm{mM})$ was placed in a test tube and then mixed. The absorbance at $266 \mathrm{~nm}$ was measured in a UV-vis spectrophotometer (UNICO Model UV2150, Dayton, NJ, USA) using a quartz cell. The measurement at T1 was taken after $60 \mathrm{~s}$ of reaction. The difference between $\mathrm{T} 1$ and $\mathrm{T} 0$ was used to obtain the activity of the enzyme. The results are expressed as $\mathrm{U} \mathrm{g}^{-1} \mathrm{TP}$, where $\mathrm{U}$ is equal to one micromole of oxidized ascorbate per milliliter per minute. 
Glutathione peroxidase (GPX) (EC 1.11.1.9) was determined with the method of Xue et al. [46]. First, $200 \mu \mathrm{L}$ of the enzyme extract, $400 \mu \mathrm{L}$ of reduced glutathione (GSH, $0.1 \mathrm{mM}$ ), and $200 \mu \mathrm{L}$ of $\mathrm{Na}_{2} \mathrm{HPO}_{4}(0.067 \mathrm{M})$ were mixed in a tube. The mixture was preheated in a water bath at $25^{\circ} \mathrm{C}$ for $5 \mathrm{~min}$, and then $200 \mu \mathrm{L}$ of $\mathrm{H}_{2} \mathrm{O}_{2}(1.3 \mathrm{mM})$ were added to start the catalytic reaction for $10 \mathrm{~min}$ at a temperature of $26^{\circ} \mathrm{C}$. The reaction was stopped by adding $1000 \mu \mathrm{L}$ of $1 \%$ trichloroacetic acid. The extraction was placed in an ice bath for $30 \mathrm{~min}$ and centrifuged at $1000 \times g$ for $10 \mathrm{~min}$ at $4{ }^{\circ} \mathrm{C}$. To evaluate glutathione peroxidase, $480 \mu \mathrm{L}$ of the supernatant, $1200 \mu \mathrm{L}$ of $\mathrm{Na}_{2} \mathrm{HPO}_{4}(0.32 \mathrm{M})$, and $320 \mu \mathrm{L}$ of $1 \mathrm{mM}$ 5,5-dithio-bis-2nitrobenzoic acid (DTNB) were mixed in a tube. The absorbance at $412 \mathrm{~nm}$ was measured using a UV-vis spectrophotometer (UNICO Model UV2150 Spectrophotometer, Dayton, NJ, USA) using a quartz cell. The results are expressed as $\mathrm{U} \mathrm{g}^{-1} \mathrm{TP}$, where $\mathrm{U}$ is equal to the millimole equivalent of reduced glutathione (GSH) per milliliter per minute.

Phenylalanine ammonia lyase (PAL) (EC 4.3.1.5) was determined according to the method of Sykłowska-Baranek et al. [47]. An extraction was carried out by mixing $100 \mu \mathrm{L}$ of the enzyme extract and $900 \mu \mathrm{L}$ of L-phenylalanine $(6 \mathrm{mM})$, incubating the mixture at $40{ }^{\circ} \mathrm{C}$ for $30 \mathrm{~min}$, and then stopping the reaction by adding $250 \mu \mathrm{L}$ of $\mathrm{HCl}(5 \mathrm{~N})$. The samples were placed in a bath of ice, and $750 \mu \mathrm{L}$ of distilled water were added. The absorbance at $290 \mathrm{~nm}$ was measured in a UV-vis spectrophotometer (UNICO Model UV2150 Spectrophotometer, Dayton, NJ, USA) using a quartz cell. The results are expressed as $\mathrm{U} \mathrm{g}^{-1} \mathrm{TP}$, where $\mathrm{U}$ is equal to the micromole equivalent of trans-cinnamic acid per milliliter per minute.

\subsubsection{Non-Enzymatic Antioxidant Compounds and Antioxidant Capacity}

Phenols, expressed as milligrams per gram of dry weight $\left(\mathrm{mg} \mathrm{g}^{-1} \mathrm{DW}\right)$, were determined using the Folin-Ciocalteu reagent, as described by Singleton et al. [48]. First, $200 \mathrm{mg}$ of lyophilized tissue were extracted by adding $1000 \mu \mathrm{L}$ of a water/acetone solution (1:1). The mixture was stirred for $30 \mathrm{~s}$ and centrifuged in a centrifuge (OHAUS Frontier Model FC5515 R, Parsippany, NJ, USA) at $17,500 \times g$ for $10 \mathrm{~min}$ at $4{ }^{\circ} \mathrm{C}$. To evaluate the phenolic compounds, $18 \mu \mathrm{L}$ of the supernatant, $70 \mu \mathrm{L}$ of Folin-Ciocalteu reagent $(0.2 \mathrm{~N}), 175 \mu \mathrm{L}$ of $20 \%$ sodium carbonate $\left(\mathrm{Na}_{2} \mathrm{CO}_{3}\right)$, and $1740 \mathrm{~mL}$ of distilled water were mixed. Then, the mixture was placed in a homogenization vortex for $30 \mathrm{~s}$ before being placed in a $45^{\circ} \mathrm{C}$ water bath for $30 \mathrm{~min}$. Finally, the reading was taken at an absorbance of $750 \mathrm{~nm}$ using a quartz cell in a UV-vis spectrophotometer (UNICO Model UV2150 Spectrophotometer, Dayton, NJ, USA).

Flavonoids (mg $100 \mathrm{~g}^{-1} \mathrm{DW}$ ) were evaluated with the method of Arvouet-Grand et al. [49]. For extraction, $20 \mathrm{mg}$ of lyophilized tissue were placed in a test tube, where $2000 \mu \mathrm{L}$ of reagent-grade methanol were added and stirred for 30 until the mixture was homogenized. The mixture was filtered on No. 1 Whatman paper. For quantification, $2000 \mu \mathrm{L}$ of the extract and $2000 \mu \mathrm{L}$ of $2 \%$ methanolic aluminum trichloride $\left(\mathrm{AlCl}_{3}\right)$ solution were added to a test tube and allowed to stand for $20 \mathrm{~min}$ in the dark. The reading was then taken in a UV-vis spectrophotometer (UNICO Model UV2150 Spectrophotometer, Dayton, NJ, USA) at a wavelength of $415 \mathrm{~nm}$ using a quartz cell.

Glutathione (mmol $100 \mathrm{~g}^{-1} \mathrm{DW}$ ) was determined using the method of Xue et al. [46] by means of a 5,5-dithio-bis-2 nitrobenzoic acid (DTNB) reaction. A mixture of $0.480 \mathrm{~mL}$ of the extract, $2.2 \mathrm{~mL}$ of sodium dibasic phosphate $\left(\mathrm{Na}_{2} \mathrm{HPO}_{4}\right.$ at $\left.0.32 \mathrm{M}\right)$, and $0.32 \mathrm{~mL}$ of the DTNB dye $(1 \mathrm{mM})$ was placed in a test tube. Then, the mixture was vortexed and read on a UV-Vis spectrophotometer (UNICO Model UV2150 Spectrophotometer, Dayton, NJ, USA) at $412 \mathrm{~nm}$ using a quartz cell.

The antioxidant capacity was determined using the DPPH (2,2-diphenyl-1-picrylhydrazyl) radical according to the method of Brand-Williams et al. [50]. The hydrophilic compounds were determined using the enzymatic extract with a phosphate buffer at pH $7(0.1 \mathrm{M})$, and a hexane/acetone extracting solution was used for the lipophilic compounds. The total antioxidant capacity was obtained by the sum of hydrophilic and lipophilic compounds [51]. The antioxidant capacity was expressed as equivalent vitamin $C\left(\mathrm{mg} \mathrm{g}^{-1} \mathrm{DW}\right)$. 


\subsection{Statistical Analysis}

The experiments were established in a randomized complete block design, and four replications per treatment were considered. An analysis of variance and a mean comparison test were performed with Fisher's least significant difference method $(p \leq 0.05)$. The entire process was carried out using the Infostat software (2020).

\section{Conclusions}

The use of $\mathrm{SiO}_{2} \mathrm{NPs}$ in the production of Lilium proved to be an effective alternative to improve the shelf life of flowers. However, it is important to consider the route of application, as the results of our chosen routes were different. In this study, it was consistently observed that the foliar application of $\mathrm{SiO}_{2} \mathrm{NPs}$ was more effective than the soil application in improving the antioxidant system of plants, which resulted in a longer shelf life. The results showed a greater shelf life of the flowers; greater contents of $\mathrm{Mg}, \mathrm{P}$, and S; more photosynthetic pigments; and greater glutathione peroxidase, phenols, and antioxidant activity. All of these positive impacts can increase the quality of flowers.

Therefore, implementing the use of $\mathrm{SiO}_{2} \mathrm{NPs}$ in the production of flowers, such as Lilium and other species of commercial interest, may be an excellent option to improve the quality of flowers and extend their shelf life.

Author Contributions: Conceptualization, A.J.-M. and G.C.-P.; methodology, J.F.S.-N., M.d.S.G.-G. and Y.G.-G.; formal analysis and resources, A.B.-M., A.B.M.-D., M.d.S.G.-G. and S.G.-M.; writingoriginal draft preparation, J.F.S.-N. and Y.G.-G.; writing—review and editing, A.J.-M., G.C.-P., A.B.-M., A.B.M.-D. and S.G.-M. All authors have read and agreed to the published version of the manuscript.

Funding: This research received no external funding.

Institutional Review Board Statement: Not applicable.

Informed Consent Statement: Not applicable.

Data Availability Statement: Not applicable.

Conflicts of Interest: The authors declare no conflict of interest.

\section{References}

1. Xu, J.; Chai, N.; Zhang, T.; Zhu, T.; Cheng, Y.; Sui, S.; Li, M.; Liu, D. Prediction of temperature tolerance in Lilium based on distribution and climate data. iScience 2021, 24, 102794. [CrossRef] [PubMed]

2. Zhou, J.; An, R.; Huang, X. Genus Lilium: A review on traditional uses, phytochemistry and pharmacology. J. Ethnopharmacol. 2021, 270, 113852. [CrossRef] [PubMed]

3. Naing, A.H.; Kim, C.K. Application of nano-silver particles to control the postharvest biology of cut flowers: A review. Sci. Hortic. 2020, 270, 109463. [CrossRef]

4. Yan, X.; Cao, Q.-Z.; He, H.-B.; Wang, L.-J.; Jia, G.-X. Functional analysis and expression patterns of members of the FLOWERING LOCUS T (FT) gene family in Lilium. Plant Physiol. Biochem. 2021, 163, 250-260. [CrossRef] [PubMed]

5. El-Sayed, I.M.; El-Ziat, R.A. Utilization of environmentally friendly essential oils on enhancing the postharvest characteristics of Chrysanthemum morifolium Ramat cut flowers. Heliyon 2021, 7, e05909. [CrossRef] [PubMed]

6. Yang, Y.; Qin, N.; Huang, J.; Guo, A.; Kang, X.; Li, S.; Xing, G. Dynamic changes of pectin epitopes and daylily tepals during flower opening and senescence of Hemerocallis citrina. Sci. Hortic. 2021, 288, 110367. [CrossRef]

7. Shabanian, S.; Nasr Esfahani, M.; Karamian, R.; Tran, L.-S.P. Physiological and biochemical modifications by postharvest treatment with sodium nitroprusside extend vase life of cut flowers of two gerbera cultivars. Postharvest Biol. Technol. 2018, 137, 1-8. [CrossRef]

8. Soleimani Aghdam, M.; Naderi, R.; Sarcheshmeh, M.A.A.; Babalar, M. Amelioration of postharvest chilling injury in Anthurium cut flowers by $\gamma$-aminobutyric acid (GABA) treatments. Postharvest Biol. Technol. 2015, 110, 70-76. [CrossRef]

9. Rajput, V.D.; Minkina, T.; Feizi, M.; Kumari, A.; Khan, M.; Mandzhieva, S.; Sushkova, S.; El-ramady, H.; Verma, K.K.; Singh, A.; et al. Effects of silicon and silicon-based nanoparticles on rhizosphere microbiome, plant stress and growth. Biology. 2021, 10, 791. [CrossRef]

10. Verma, K.K.; Anas, M.; Chen, Z.; Rajput, V.D.; Malviya, M.K.; Verma, C.L.; Singh, R.K.; Singh, P.; Song, X.-P.; Li, Y.-R. Silicon supply improves leaf gas exchange, antioxidant defense system and growth in Saccharum officinarum responsive to water limitation. Plants 2020, 9, 1032. [CrossRef] [PubMed] 
11. Hatami, M.; Khanizadeh, P.; Bovand, F.; Aghaee, A. Silicon nanoparticle-mediated seed priming and Pseudomonas spp. inoculation augment growth, physiology and antioxidant metabolic status in Melissa officinalis L. plants. Ind. Crops Prod. 2021, $162,113238$. [CrossRef]

12. Mukarram, M.; Khan, M.M.A.; Corpas, F.J. Silicon nanoparticles elicit an increase in lemongrass (Cymbopogon flexuosus (Steud.) Wats) agronomic parameters with a higher essential oil yield. J. Hazard. Mater. 2021, 412, 125254. [CrossRef]

13. Xia, L.; Huang, H.; Feng, W.; Chen, Y. Silica nanoparticles boost plant resistance against pathogens. Sci. Bull. 2021, 66, 1151-1153. [CrossRef]

14. Zhang, Y.; Zhong, D.; Liu, Z.; Gao, J. Study on the physiological, cellular, and morphological aspects of the postharvest development of cut lily flowers. Hortic. Plant J. 2021, 7, 149-158. [CrossRef]

15. Lu, N.; Wu, L.; Shi, M. Selenium enhances the vase life of Lilium longiflorum cut flower by regulating postharvest physiological characteristics. Sci. Hortic. 2020, 264, 109172. [CrossRef]

16. Çelikel, F.G.; Reid, M.S.; Jiang, C.-Z. Postharvest physiology of cut Gardenia jasminoides flowers. Sci. Hortic. 2020, $261,108983$. [CrossRef]

17. Akhtar, G.; Rajwana, I.A.; Sajjad, Y.; Shehzad, M.A.; Amin, M.; Razzaq, K.; Ullah, S.; Faried, H.N.; Farooq, A. Do natural leaf extracts involve regulation at physiological and biochemical levels to extend vase life of gladiolus cut flowers? Sci. Hortic. 2021, 282, 110042. [CrossRef]

18. Rizwan, M.; Ali, S.; Qayyum, M.F.; Ok, Y.S.; Adrees, M.; Ibrahim, M.; Zia-ur-Rehman, M.; Farid, M.; Abbas, F. Effect of metal and metal oxide nanoparticles on growth and physiology of globally important food crops: A critical review. J. Hazard. Mater. 2017, 322, 2-16. [CrossRef] [PubMed]

19. Awasthi, G.; Singh, T.; Tiwari, Y.; Awasthi, A.; Tripathi, R.D.; Shrivastava, S.; Vajpayee, P.; Kumar, A.; Awasthi, K.K. A review on nanotechnological interventions for plant growth and production. Mater. Today Proc. 2020, 31, 685-693. [CrossRef]

20. Kumar, A.; Gupta, K.; Dixit, S.; Mishra, K.; Srivastava, S. A review on positive and negative impacts of nanotechnology in agriculture. Int. J. Environ. Sci. Technol. 2019, 16, 2175-2184. [CrossRef]

21. Mahto, R.; Rani, P.; Bhardwaj, R.; Singh, R.K.; Prasad, S.K.; Rakshit, A. Nanotechnology: A potential approach for abiotic stress management. In Food Science, Technology and Nutrition; Woodhead Publishing: Sawston, UK, 2021; pp. 249-264. ISBN 978-0-12-820092-6.

22. Lala, S. Nanoparticles as elicitors and harvesters of economically important secondary metabolites in higher plants: A review. IET Nanobiotechnol. 2021, 15, 28-57. [CrossRef] [PubMed]

23. Rivero-Montejo, S.; Vargas-Hernandez, M.; Torres-Pacheco, I. Nanoparticles as Novel Elicitors to Improve Bioactive Compounds in Plants. Agriculture 2021, 11, 134. [CrossRef]

24. Juárez-Maldonado, A.; Ortega-Ortiz, H.; González-Morales, S.; Morelos-Moreno, Á.; Cabrera-de la Fuente, M.; Sandoval-Rangel, A.; Cadenas-Pliego, G.; Benavides-Mendoza, A. Nanoparticles and nanomaterials as plant biostimulants. Int. J. Mol. Sci. 2019, 20, 162. [CrossRef]

25. Juárez-Maldonado, A.; Tortella, G.; Rubilar, O.; Fincheira, P.; Benavides-Mendoza, A. Biostimulation and toxicity: The magnitude of the impact of nanomaterials in microorganisms and plants. J. Adv. Res. 2021, 31, 113-126. [CrossRef] [PubMed]

26. Dawa, K.; Zaghloul, M.; Ahmed, H.I.; Hamad, K. Impact of foliar application with iron, zinc, silicon nano particles and yeast on growth, yield and water use efficiency of tomato plants under water stress conditions. J. Plant Prod. 2020, 11, 523-530. [CrossRef]

27. Malhotra, C.C.; Kapoor, R.; Ganjewala, D. Alleviation of abiotic and biotic stresses in plants by silicon supplementation. Sci. Agric. 2016, 13, 59-73. [CrossRef]

28. Hoffmann, J.; Berni, R.; Hausman, J.F.; Guerriero, G. A review on the beneficial role of silicon against salinity in non-accumulator crops: Tomato as a model. Biomolecules 2020, 10, 1284. [CrossRef]

29. Islam, W.; Tayyab, M.; Khalil, F.; Hua, Z.; Huang, Z.; Chen, H.Y.H. Silicon-mediated plant defense against pathogens and insect pests. Pestic. Biochem. Physiol. 2020, 168, 104641. [CrossRef]

30. Nourozi, E.; Hosseini, B.; Maleki, R.; Mandoulakani, B.A. Pharmaceutical important phenolic compounds overproduction and gene expression analysis in Dracocephalum kotschyi hairy roots elicited by $\mathrm{SiO}_{2}$ nanoparticles. Ind. Crops Prod. 2019, 133, 435-446. [CrossRef]

31. Hedayati, A.; Hosseini, B.; Palazon, J.; Maleki, R. Improved tropane alkaloid production and changes in gene expression in hairy root cultures of two Hyoscyamus species elicited by silicon dioxide nanoparticles. Plant Physiol. Biochem. 2020, 155, 416-428. [CrossRef]

32. de Sousa, A.; Saleh, A.M.; Habeeb, T.H.; Hassan, Y.M.; Zrieq, R.; Wadaan, M.A.M.; Hozzein, W.N.; Selim, S.; Matos, M.; AbdElgawad, H. Silicon dioxide nanoparticles ameliorate the phytotoxic hazards of aluminum in maize grown on acidic soil. Sci. Total Environ. 2019, 693, 133636. [CrossRef]

33. Xie, X.; Weiss, D.J.; Weng, B.; Liu, J.; Lu, H.; Yan, C. The short-term effect of cadmium on low molecular weight organic acid and amino acid exudation from mangrove (Kandelia obovata (S., L.) Yong) roots. Environ. Sci. Pollut. Res. 2013, 20, 997-1008. [CrossRef]

34. Zuverza-Mena, N.; Martínez-Fernández, D.; Du, W.; Hernandez-Viezcas, J.A.; Bonilla-Bird, N.; López-Moreno, M.L.; Komárek, M.; Peralta-Videa, J.R.; Gardea-Torresdey, J.L. Exposure of engineered nanomaterials to plants: Insights into the physiological and biochemical responses-A review. Plant Physiol. Biochem. 2017, 110, 236-264. [CrossRef]

35. Liang, Y.; Zhang, W.; Chen, Q.; Liu, Y.; Ding, R. Effect of exogenous silicon (Si) on $\mathrm{H}^{+}$-ATPase activity, phospholipids and fluidity of plasma membrane in leaves of salt-stressed barley (Hordeum vulgare L.). Environ. Exp. Bot. 2006, 57, 212-219. [CrossRef] 
36. Le, V.N.; Rui, Y.; Gui, X.; Li, X.; Liu, S.; Han, Y. Uptake, transport, distribution and bio-effects of $\mathrm{SiO}_{2}$ nanoparticles in Bt-transgenic cotton. J. Nanobiotechnol. 2014, 12, 50. [CrossRef] [PubMed]

37. González-Moscoso, M.; Martínez-Villegas, N.V.; Meza-Figueroa, D.; Rivera-Cruz, M.C.; Cadenas-Pliego, G.; Juárez-Maldonado, A. $\mathrm{SiO}_{2}$ Nanoparticles improve nutrient uptake in tomato plants developed in the presence of arsenic. Rev. BioCiencias 2021, 8, 1-25.

38. Tripathi, D.K.; Singh, S.; Singh, S.; Pandey, R.; Singh, V.P.; Sharma, N.C.; Prasad, S.M.; Dubey, N.; Chauhan, D.K. An overview on manufactured nanoparticles in plants: Uptake, translocation, accumulation and phytotoxicity. Plant Physiol. Biochem. 2016, 110, 2-12. [CrossRef]

39. Alsaeedi, A.; El-Ramady, H.; Alshaal, T.; El-Garawany, M.; Elhawat, N.; Al-Otaibi, A. Silica nanoparticles boost growth and productivity of cucumber under water deficit and salinity stresses by balancing nutrients uptake. Plant Physiol. Biochem. 2019, 139, 1-10. [CrossRef]

40. Steiner, A.A. A universal method for preparing nutrient solutions of a certain desired composition. Plant Soil 1961, 15, 134-154. [CrossRef]

41. Pinedo-Guerrero, Z.H.; Cadenas-Pliego, G.; Ortega-Ortiz, H.; González-Morales, S.; Benavides-Mendoza, A.; Valdés-Reyna, J.; Juárez-Maldonado, A. Form of silica improves yield, fruit quality and antioxidant defense system of tomato plants under salt stress. Agriculture 2020, 10, 367. [CrossRef]

42. Nagata, M.; Yamashita, I. Simple method for simultaneous determination of chlorophyll and carotenoids in tomato fruit. Nippon Shokuhin Kogyo Gakkaishi 1992, 39, 925-928. [CrossRef]

43. Bradford, M.M. A rapid and sensitive method for the quantitation of microgram quantities of protein utilizing the principle of protein-dye binding. Anal. Biochem. 1976, 72, 248-254. [CrossRef]

44. Dhindsa, R.S.; Plumb-dhindsa, P.; Thorpe, T.A. Leaf senescence: Correlated with increased levels of membrane permeability and lipid peroxidation, and decreased levels of superoxide dismutase and catalase. J. Exp. Bot. 1981, 32, 93-101. [CrossRef]

45. Nakano, Y.; Asada, K. Purification of ascorbate peroxidase in spinach chloroplasts; its inactivation in ascorbate-depleted medium and reactivation by monodehydroascorbate radical. Plant Cell Physiol. 1987, 28, 131-140. [CrossRef]

46. Xue, T.; Hartikainen, H.; Piironen, V. Antioxidative and growth-promoting effect of selenium on senescing lettuce. Plant Soil 2001, 237, 55-61. [CrossRef]

47. Sykłowska-Baranek, K.; Pietrosiuk, A.; Naliwajski, M.R.; Kawiak, A.; Jeziorek, M.; Wyderska, S.; Łojkowska, E.; Chinou, I. Effect of l-phenylalanine on PAL activity and production of naphthoquinone pigments in suspension cultures of Arnebia euchroma (Royle) Johnst. Vitr. Cell. Dev. Biol.-Plant 2012, 48, 555-564. [CrossRef] [PubMed]

48. Singleton, V.L.; Orthofer, R.; Lamuela-Raventos, R.M. Analisys of total phenols and other oxidation sobstrates and antioxidants by means of Folin Ciocalteau reagent. Methods Enzymol. 1999, 299, 152-178.

49. Arvouet-Grand, A.; Vennat, B.; Pourrat, A.; Legret, P. Standardization of propolis extract and identification of principal constituents. J. Pharm. Belg. 1994, 49, 462-468. [PubMed]

50. Brand-Williams, W.; Cuvelier, M.E.; Berset, C. Use of a free radical method to evaluate antioxidant activity. LWT-Food Sci. Technol. 1995, 28, 25-30. [CrossRef]

51. Arnao, M.B.; Cano, A.; Acosta, M. The hydrophilic and lipophilic contribution to total antioxidant activity. Food Chem. 2001, 73, 239-244. [CrossRef] 